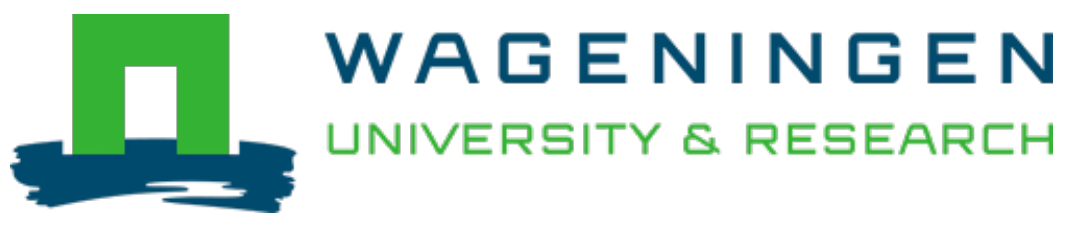

\title{
Investigation of the presence of biogenic amines and ethyl carbamate in kenkey made with maize and maize-cowpea mixtures as influenced by process conditions
}

Food Additives and Contaminants

Nout, M.J.R.; Nche, P.F.; Hollman, P.C.H.

https://doi.org/10.1080/02652039409374238

This publication is made publicly available in the institutional repository of Wageningen University and Research, under the terms of article $25 \mathrm{fa}$ of the Dutch Copyright Act, also known as the Amendment Taverne. This has been done with explicit consent by the author.

Article 25 fa states that the author of a short scientific work funded either wholly or partially by Dutch public funds is entitled to make that work publicly available for no consideration following a reasonable period of time after the work was first published, provided that clear reference is made to the source of the first publication of the work.

This publication is distributed under The Association of Universities in the Netherlands (VSNU) 'Article $25 \mathrm{fa}$ implementation' project. In this project research outputs of researchers employed by Dutch Universities that comply with the legal requirements of Article $25 \mathrm{fa}$ of the Dutch Copyright Act are distributed online and free of cost or other barriers in institutional repositories. Research outputs are distributed six months after their first online publication in the original published version and with proper attribution to the source of the original publication.

You are permitted to download and use the publication for personal purposes. All rights remain with the author(s) and / or copyright owner(s) of this work. Any use of the publication or parts of it other than authorised under article $25 \mathrm{fa}$ of the Dutch Copyright act is prohibited. Wageningen University \& Research and the author(s) of this publication shall not be held responsible or liable for any damages resulting from your (re)use of this publication.

For questions regarding the public availability of this publication please contact openscience.library@wur.nl 


\title{
Investigation of the presence of biogenic amines and ethyl carbamate in kenkey made with maize and maize-cowpea mixtures as influenced by process conditions
}

\author{
M. J. R. NOUT $\uparrow \S$, P. F. NCHE $†$ and P. C. H. HOLLMAN $\ddagger$ \\ †Department of Food Science, Agricultural University, Bomenweg 2, 6703 HD, \\ Wageningen, The Netherlands; ‡DLO State Institute for Quality Control of Agricultural \\ Products (RIKILT-DLO), Wageningen, The Netherlands
}

(Received II May 1993; revised I September 1993; accepted 6 October 1993)

\begin{abstract}
Kenkey is a fermented and cooked maize dough from Ghana. The effect of manufacturing conditions, i.e. fermentation and cooking, and of protein-enrichment by cowpea addition (20\% of total weight) on the occurrence of toxic microbial products, namely biogenic amines and ethyl carbamate, were investigated. The levels of biogenic amines in all-maize kenkey were very low (total amines $<60 \mathrm{ppm}$ ), but were significantly increased by addition of red cowpea (total amines $<200 \mathrm{ppm}$, mainly cadaverine and tyramine), and even more by white cowpea (total amines $<500 \mathrm{ppm}$, mainly putrescine and tyramine). Histamine was absent $(<5 \mathrm{ppm})$ in all samples. The effects of fermentation and cooking were less pronounced than the influence of cowpea addition. Prolonged cooking of kenkey resulted in lower levels of putrescine, but did not significantly reduce tyramine levels. Ethyl carbamate levels were negligible $(<11 \mathrm{ppb})$ in all treatments.
\end{abstract}

Keywords: maize, cowpea, kenkey, biogenic amines, ethyl carbamate

\section{Introduction}

Biogenic amines and ethyl carbamate are toxic substances which can be formed in foods, mainly by microbial enzymic activity. The biogenic amines of toxicological relevance include histamine, tyramine, $\beta$-phenylethylamine, tryptamine, putrescine and cadaverine (Stratton et al. 1991). The major pathway of formation in foods is by decarboxylation of free amino acids. Various lactic acid bacteria and Enterobacteriaceae possess the required decarboxylase activity (Stratton et al. 1991).

Ethyl carbamate (urethane) has mutagenic and carcinogenic properties (Mirvish 1968), and can be formed from reaction with ethanol and naturally occurring carbamyl phosphate during the fermentation process. Both compounds mainly result from yeast metabolism; ethyl carbamate can also be formed from reaction with ethanol and urea naturally produced from amino acids such as arginine and citrulline (Ough 1976, Matsudo et al. 1993).

Kenkey is a popular ready-to-eat staple food from Ghana. Basically, it consists of fermented maize dough shaped into balls wrapped in leaves and cooked in water (Muller 1970, Muller and Nyarko-Mensah 1972, Nche et al. 1994). The major functional microorganisms in the fermentation are lactic acid bacteria, but yeasts

$\S$ To whom correspondence should be addressed. 
and Enterobacteriaceae may occur as well in variable quantities. In addition, it is also possible to produce acceptable protein-enriched kenkey (Nche et al. 1994) by substituting $20 \%$ of the maize used with cowpea (Vigna unguiculata) which, in Ghana, is more popular than soya beans. The enrichment with cowpea results in increased availability of amino acids from which biogenic amines may also be formed.

The presence of varying levels of biogenic amines in, for example, cheese, sausage, wine, beer, soya sauce and miso (Stratton et al. 1991), and of ethyl carbamate in distilled spirits and wines, and fermented foods e.g. bread, soya sauce, miso and yeast spread (Diachenko et al. 1992) have been reported. In the absence of data concerning kenkey, the present investigation was carried out to evaluate the influence of processing, choice of ingredients and of representative microorganisms on the possible accumulation of biogenic amines and ethyl carbamate in kenkey made with maize or maize-cowpea mixtures.

\section{Materials and methods}

Maize (Zea mays cv obaatanba) and red and white cowpeas (Vigna unguiculata cvs benpla and asontem, respectively) were obtained from the Crops Research Institute, CSIR, Kwadaso, Ghana.

\section{Manufacture of kenkey}

Kenkey was prepared on a laboratory-scale according to Nche et al. (1994). In short, $1 \mathrm{~kg}$ of maize kernels (or a 4:1 mixture of maize and cowpea) was soaked for 2 days at $4^{\circ} \mathrm{C}$ or $30^{\circ} \mathrm{C}$ (regular process) in 31 of tap water. The soak water was drained and discarded, and the grain coarsely ground in a hammer mill (Fritsch Pulverisette Type 14.702, Marius Instruments, Utrecht, The Netherlands) with rotor and sieve ( $4 \mathrm{~mm}$ aperture) and made into a dough by adding water $(1: 3 \mathrm{v} / \mathrm{w})$. The dough was placed in a 11 beaker, covered and allowed to ferment naturally (regular process) for 3 days at $30^{\circ} \mathrm{C}$. Alternatively, the dough was inoculated prior to fermentation, as described below. The fermented dough was divided into two equal portions, one of which was slurried with water $(3: 1 \mathrm{v} / \mathrm{w})$ and stir-cooked to gelatinization to give the aflata. The cooked and uncooked portions were mixed, kneaded and dumplings were made and wrapped, first in polyethylene film followed by aluminium foil. The wrapped dumplings were immersed in boiling water to cook for $1 \mathrm{~h}$ (regular process) or $3 \mathrm{~h}$. Samples for cheınical analysis were prepared by grinding $100 \mathrm{~g}$ of composite sample from duplicate treatments, followed by frozen storage at $-20^{\circ} \mathrm{C}$ until analysis. Chemical analyses were carried out in duplicate.

\section{Inoculum preparation}

Lactic acid bacteria which had been isolated previously from kenkey (Nche et al. 1994) included Lactobacillus plantarum, L. confusus, L. brevis and Pediococcus pentosaceus. Pure cultures were grown in MRS broth (Merck Art. 10661 ) at $30^{\circ} \mathrm{C}$ for $24 \mathrm{~h}$. At the start of the dough fermentation period, a mixed inoculation of maize dough was achieved by adding $1 \mathrm{ml}$ of each MRS culture per $100 \mathrm{~g}$ of dough, followed by thorough mixing. Similarly, four unidentified yeast isolates obtained from kenkey were pre-grown in Malt Extract Broth (Oxoid CM57) at $30^{\circ} \mathrm{C}$ for $24 \mathrm{~h}$. Inoculation of maize dough was as described above. 


\section{Determination of biogenic amines}

A portion of $15 \mathrm{~g}$ dry matter was homogenized with $50 \mathrm{ml} 5 \%$ trichloroacetic acid at $70^{\circ} \mathrm{C}$ in a $100 \mathrm{ml}$ glass beaker using a Waring blender. After cooling to room temperature, the mixture was transferred quantitatively into a $100 \mathrm{ml}$ volumetric flask and made up to the mark with $5 \%$ trichloroacetic acid. After mixing, a $50 \mathrm{ml}$ portion was transferred into a centrifuge tube and centrifuged at $2500 \mathrm{~g}$ for $10 \mathrm{~min}$. The supernatant was filtered through filter paper (Schleicher and Schull $5951 / 2$, no. 311645 ). A $25 \mathrm{ml}$ aliquot of filtrate was transferred into a $100 \mathrm{ml}$ volumetric flask and diluted to the mark with distilled water. The diluted filtrate was filtered again through a $0.45 \mu \mathrm{m}$ pore size filter (Millipore filter, type HVLP 04700). Biogenic amines were separated by ion-exchange liquid chromatography (LC) and detected with a fluorescence detector after post-column derivatization with $o$-phthalaldehyde adapted from Walters (1984). The detection limit was $1 \mathrm{mg} / \mathrm{kg}$, and data had a coefficient of variation of $10 \%$. The LC conditions were as follows: column: stationary phase Zorbax 300 SCX strong cation-exchange resin (Dupont no. 28768); mobile phase (eluent): 70 parts by volume of $0 \cdot 1 \mathrm{M}$ phosphate buffer, $\mathrm{pH} 6 \cdot 1$, and 30 parts by volume of methanol; elution rate: $1.0 \mathrm{ml} / \mathrm{min}$. Post-column derivatization was carried out at $45^{\circ} \mathrm{C}$ in a $900 \times 0.5 \mathrm{~mm}$ i.d. Teflon reactor spiral. The reagent for post-column derivatization was added at $0.8 \mathrm{ml} / \mathrm{min}$ and consisted of freshly mixed solutions of A and B. Solution A: $12.5 \mathrm{~g}$ boric acid (Merck-art. 165 ) in $475 \mathrm{ml}$ distilled water adjusted with $\mathrm{KOH}$ to $\mathrm{pH} 10 \cdot 4$. Solution B: $300 \mathrm{mg}$ o-phthalaldehyde (Merck art. 11452) in $5 \mathrm{ml}$ ethanol 96\% (Merck art. 983) to which $100 \mu \mathrm{l} 2$-mercaptoethanol (Merck art. 805740) was added. Detection was carried out with a fluorescence detector (Waters type 420 with lamp 78245) with $\lambda_{\text {excitation }}=338 \mathrm{~nm}$ and $\lambda_{\text {emission }}>420 \mathrm{~nm}$. Samples were extracted in duplicate. Each extract was chromatographed twice. The reported data are means of the four determinations.

\section{Detection of ethyl carbamate}

Ten $\mathrm{g}$ of sample was homogenized and extracted in duplicate with methylene chloride according to the procedure for bread (Canas et al. 1989). Each concentrated extract was analysed in duplicate by gas liquid chromatography (GLC) according to the method of Kesselmans et al. (1986), applying the following conditions: column: $\mathrm{CP}$ wax-52 $\mathrm{CB}$, WCOT fused silica length $50 \mathrm{~m}$, inner diameter $0.32 \mathrm{~mm}$; carrier $\mathrm{N}_{2}(120 \mathrm{kPa})$, make-up $\mathrm{He}(115 \mathrm{kPa})$, detector $\mathrm{H}_{2}$ (67 kPA), air (102 kPa); NPD-detector in NP-mode (potassium tablet); injection volume $1.0 \mu \mathrm{l}$ on-column; temperature programme: $20^{\circ} \mathrm{C}$ for $20 \mathrm{~s}, 20-87^{\circ} \mathrm{C}$ in $40 \mathrm{~s}$, $87-180^{\circ} \mathrm{C}$ at a rate of $8^{\circ} \mathrm{C}$ per min, $180-190^{\circ} \mathrm{C}$ at a rate of $10^{\circ} \mathrm{C}$ per min, $190^{\circ} \mathrm{C}$ for $20 \mathrm{~min}$. The recoveries for ethyl carbamate (EC) in spiked kenkey samples varied from 45 to $50 \%$. The detection limit of EC in extract by GLC was $10 \mu \mathrm{g} / \mathrm{l}$, corresponding to $11 \mu \mathrm{g} / \mathrm{kg}(11 \mathrm{ppb})$ in the original sample. Data had a coefficient of variation of $5.5 \%$ at the $200 \mu \mathrm{g} / \mathrm{kg}(200 \mathrm{ppb})$ level.

\section{Results and discussion}

Table 1 shows the treatments investigated, and the levels of cadaverine, histamine, putrescine, tryptamine and tyramine determined expressed as $\mathrm{mg} / \mathrm{kg}$ sample dry weight. In addition, the $\mathrm{pH}$ of the fermented dough prior to cooking was recorded to serve as an index of fermentation. When soaking and dough 
Table 1. Biogenic amines (mg/kg dry matter) in maize- and maize-cowpea-based kenkey processing stages.

\begin{tabular}{|c|c|c|c|c|c|c|c|}
\hline \multirow[b]{3}{*}{ Treatment code } & \multicolumn{7}{|c|}{ Raw material } \\
\hline & \multicolumn{2}{|c|}{$100 \%$ maize } & \multirow{2}{*}{$\frac{\begin{array}{c}80 \% \text { maize } \\
20 \% \text { red } C P^{a}\end{array}}{C}$} & \multicolumn{4}{|c|}{$\begin{array}{c}80 \% \text { maize } \\
20 \% \text { white } \mathrm{CP}\end{array}$} \\
\hline & A & B & & D & $\mathrm{D}^{\prime}$ & E & $\mathrm{F}$ \\
\hline \multicolumn{8}{|l|}{ Soaking ${ }^{\mathbf{b}}$ and fermentation } \\
\hline Added inoculum & - & - & - & - & & L.A.B. ${ }^{c}$ & Yeasts $^{\circ}$ \\
\hline \multicolumn{8}{|l|}{ Fermented dough } \\
\hline $\mathrm{pH}$ & 6.49 & $4 \cdot 01$ & $4 \cdot 09$ & $4 \cdot 01$ & & $3 \cdot 75$ & $4 \cdot 20$ \\
\hline Cadaverine & $<22$ & $<22$ & 100 & $<22$ & & 78 & $<22$ \\
\hline Histamine & $<5$ & $<5$ & $<5$ & $<5$ & & $<5$ & $<5$ \\
\hline Putrescine & $<11$ & $<11$ & 22 & 377 & & 89 & 244 \\
\hline Tryptamine & $<5$ & $<5$ & $<5$ & $<5$ & & $<5$ & $<5$ \\
\hline Tyramine & 78 & 11 & 56 & 200 & & 200 & 200 \\
\hline Cooked at $100^{\circ} \mathrm{C}$ & $1 \mathrm{~h}$ & $1 \mathrm{~h}$ & I h & $1 \mathrm{~h}$ & $3 \mathrm{~h}$ & $1 \mathrm{~h}$ & $1 \mathrm{~h}$ \\
\hline \multicolumn{8}{|l|}{ Kenkey } \\
\hline Cadaverine & $<25$ & $<25$ & 113 & $<25$ & $<25$ & 63 & $<25$ \\
\hline Histamine & $<5$ & $<5$ & $<5$ & $<5$ & $<5$ & $<5$ & $<5$ \\
\hline Putrescine & $<13$ & 13 & $<13$ & 325 & $<13$ & 63 & 138 \\
\hline Tryptamine & $<5$ & $<5$ & $<5$ & $<5$ & $<5$ & $<5$ & $<5$ \\
\hline Tyramine & 50 & $<13$ & 63 & 163 & 175 & 200 & 175 \\
\hline
\end{tabular}
dough.

a Cowpea.
${ }^{b}$ Whole kernels soaked for 2 days followed by grinding and 3 days fermentation of resulting

c Multi-strain mixture of lactic acid bacteria isolated from kenkey.

d Multi-strain mixture of yeasts isolated from kenkey.

incubation were carried out at $4^{\circ} \mathrm{C}$ (treatment A), no fermentation took place. This was indicated by the almost neutral $\mathrm{pH}$, as well as a very low total plate count (data not shown). In doughs, natural fermentation at $30^{\circ} \mathrm{C}$ resulted in $10^{8}-10^{9} \mathrm{cfu} / \mathrm{g}$ of lactic acid bacteria, $10^{2}-10^{3} \mathrm{cfu} / \mathrm{g}$ of yeasts, while Enterobacteriaceae could not be detected (data not shown). These levels of microorganisms are in line with those reported earlier for laboratory-made kenkey (Nche et al. 1994).

When comparing treatments $\mathrm{B}, \mathrm{C}$ and $\mathrm{D}$, an assessment of the effect of ingredients can be made. Whereas maize alone hardly enabled formation of biogenic amines, addition of $20 \%$ red cowpea caused a significant increase of cadaverine and tyramine levels, and addition of $20 \%$ white cowpea gave even higher concentrations, mainly of putrescine and tyramine. The general increase can be explained by the supply of precursor amino acids by cowpea. The different effect of red vs white cowpea could be due to different ranges and levels of free amino acids. Also, polyphenols present in red cowpea seed coat may inhibit decarboxylases (Ogun et al. 1989).

Treatments A and B allow an evaluation of the effect of natural fermentation. Although maize was shown not to be a strong precursor for biogenic amines, it was 
observed that non-fermented maize dough and kenkey (A) had a somewhat higher tyramine content compared with fermented dough and kenkey (B). These limited data suggest that in (A), formation of tyramine can be explained by the combined action of endogenous proteolytic and decarboxylating enzymes (Devi and Prasad 1992). When actively growing microorganisms are present (B), some of the free amino acids are not converted into biogenic amines. In addition, the low $\mathrm{pH}$ in the fermented dough may be inhibitory to decarboxylases causing a lower amine level.

Treatments D, E and F show the difference between natural and inoculumsupplemented fermentations. The inoculation with a mixture of lactic acid bacteria caused a strong reduction of putrescine, but cadaverine slightly increased. Addition of lactic acid bacteria had no significant effect on tyramine levels. Added yeasts had no significant effects on either cadaverine or tyramine, but caused a significant decrease of putrescine levels.

A comparison of dough and kenkey, and of treatments $\mathrm{D}$ and $\mathrm{D}^{\prime}$ indicates the effect of cooking. A 1-h cooking period (compare D, E, F-dough with D, E, Fcooked kenkey) caused a slight (non-significant) decrease of the tyramine level only; extended cooking $\left(D^{\prime}\right)$ for $3 \mathrm{~h}$ significantly reduced the putrescine level.

In general, histamine and tryptamine were absent in all samples. Non-enriched whole maize kenkey did not contain significant levels of any of the biogenic amines tested and may be regarded as a safe product with regard to amines. On the other hand, the enrichment of kenkey with $20 \%$ cowpea significantly increased the levels of biogenic amines. Not all amines are equally toxic. Histamine and tyramine are especially associated with symptoms of intoxication. Although the other amines are considered to potentiate the toxic effect of histamine and tyramine, few quantitative data about such interactions in vivo are available (Stratton et al. 1991). Histamine was absent $(<5 \mathrm{ppm})$ in all samples, but tyramine was present in detectable quantities 60-200 ppm). In particular, the tyramine concentrations in cowpeaenriched kenkey could be considered as 'moderately high' when compared with similar data for cheese (Stratton et al. 1991). Considering the present lack of knowledge about the toxicity of tyramine in the presence of cadaverine and putrescine it is not possible to simplify the results by, for example, calculating a weighted total biogenic amines level, or to compensate decreased levels of putrescine with increased cadaverine or tyramine concentrations. Taking into account that kenkey is an everyday staple food, it will nevertheless be important to minimize the level of biogenic amines in cowpea-enriched kenkey as much as possible. The data show that prolonged cooking contributes only marginally to lowering the amine levels. Consequently, it will be of interest to select lactic acid bacteria with the ability to degrade amines (Beutling 1992), and to investigate their usefulness as starter organisms with a view to obtaining low-amine enriched kenkey.

With regard to ethyl carbamate, all samples contained less than $11 \mathrm{ppb}$ (the detection limit). This appears to correspond with the reported absence of ethyl carbamate in a range of fermented foods in which yeasts were not involved as a major population (Diachenko et al. 1992) whereas levels up to $84 \mathrm{ppb}$ (soya sauce) were found in fermented foods in which alcoholic fermentation had taken place to some extent and an average of approximately $200 \mathrm{ppb}$ was reported for alcoholic beverages. The tolerance level of ethyl carbamate as applied in Canada varies from $30 \mathrm{ppb}$ in wines to $400 \mathrm{ppb}$ in distilled spirits (Diachenko et al. 1992). This implies that ethyl carbamate is not a factor of public health relevance in kenkey or in 
cowpea-enriched kenkey. Most likely, the absence of ethyl carbamate is due to inadequate levels of ethanol and/or precursors such as citrulline, arginine or urea in the product.

\section{Acknowledgements}

The technical contribution by M. M. W. Ruikes is gratefully acknowledged. The help with chromatography of biogenic amines by Mrs D. P. Venema of the State Institute for Quality Control of Agricultural Products (RIKILT-DLO), Wageningen, and with the chromatography of ethyl carbamate by Mr T. M. M. Rondags and Dr P. R. Beljaars of the Inspectorate for Health Protection, Food Inspection Service, Maastricht, The Netherlands, is highly appreciated. This project was supported by the European Community (Contract No. TS2-0267-UK 'The evaluation and improvement of traditional fermented cereals and legumes in Ghana').

\section{References}

Beutling, D., 1992, Prüfung von Starterorganismen auf ihre Befähigung zur Bildung von Histamin und Tyramin. Monatshefte für Veterinär-Medizin, 47, 587-591.

Canas, B. J., Havery, D. C., Robinson, L. R., Sullivan, M. P., Joe, F. L., JR, and Diachenko, G. W., 1989, Ethyl carbamate levels in selected fermented foods and beverages. Journal of the Association of Official Analytical Chemists, 72, 873-876.

Devi, S. R., and Prasad, M. N. V., 1992, Effect of ferulic acid on growth and hydrolytic enzyme activities of germinating maize seeds. Journal of Chemical Ecology, 18, 1981-1990.

Diachenko, G. W., Canas, B. J., Joe, F. L., and Dinovi, M., 1992, Ethyl carbamate in alcoholic beverages and fermented foods. Food Safety Assessment, edited by J. W. Finley, S. F. Robinson, and D. J. Armstrong, ACS Symposium Series No. 484 (Washington, DC: American Chemical Society), pp. 419-428.

Kesselmans, R. P. W., Cohen, M., Peeters, M. J., and Beljaars, P. R., 1986, Survey of the presence of ethyl carbamate (urethane) in alcoholic beverages (in Dutch). De Ware(n)-Chemicus, 16, 105-119.

Matsudo, T., Aoki, T., Abe, K., Fukuta, N., Higuchi, T., Sasaki, M., and Uchida, K., 1993, Determination of ethyl carbamate in soy sauce and its possible precursor. Journal of Agricultural and Food Chemistry, 41, 352-356.

Mirvish, S. S., 1968, The carcinogenic action and metabolism of urethane and $N$-hydroxyurethane Advances in Cancer Research, 11, 1-42.

Muller, H. G., 1970, Traditional cereal processing in Nigeria and Ghana. Ghana Journal of Agricultural Science, 3, 187-191.

Muller, H. G., and Nyarko-MenSAH, B., 1972, Studies on kenkey, a Ghanaian cereal food. Journal of the Science of Food and Agriculture, 23, 544-545.

Nche, P. F., NouT, M. J. R., and Rombouts, F. M., 1994, Effect of cowpea supplementation on the quality of Kenkey, a Ghanaian traditional fermented maize food. Journal of Cereal Science, (in press).

Ogun, P. O., Markakis, P., and Chenoweth, W., 1989, Effect of processing on certain antinutrients in cowpeas (Vigna unguiculata). Journal of Food Science, 54, 1084-1085.

Ough, C. S., 1976, Ethyl carbamate in fermented beverages and foods. Journal of Agricultural and Food Chemistry, 24, 323-331.

Stratton, J. E., Hutkins, R. W., and Taylor, S. L., 1991, Biogenic amines in cheese and other fermented foods-a review. Journal of Food Protection, 54, 460-470.

WALTERS, M. J., 1984, Determination of histamine in fish by liquid chromatography with post-column reaction and fluorometric detection. Journal of the Association of Official Analytical Chemists, 67, 1040-1043. 